\title{
Physico-Chemical Properties of Compost Based Waste-Recycling of Grape Fruit as Nursery Growing Medium
}

\author{
Mohammed El-Sayed El-Mahrouk ${ }^{*}$, Yaser Hassan Dewir ${ }^{1,2}$ \\ ${ }^{1}$ Horticulture Department, Faculty of Agriculture, Kafrelsheikh University, Kafr El Sheikh, Egypt \\ ${ }^{2}$ Plant Production Department, College of Food and Agriculture Science, King Saud University, Riyadh, \\ Saudi Arabia \\ Email: "Threemelmahrouk@yahoo.com
}

Received 13 November 2015; accepted 10 January 2016; published 13 January 2016

Copyright $@ 2016$ by authors and Scientific Research Publishing Inc.

This work is licensed under the Creative Commons Attribution International License (CC BY).

http://creativecommons.org/licenses/by/4.0/

(c) (9) Open Access

\section{Abstract}

The present study reports the physico-chemical properties of four compost based squeezed grape fruit wastes (SGFW) consisting of $60 \%$ SGFW $+40 \%$ chicken manure (including sawdust) (CMS) $(v / v), 80 \%$ SGFW $+20 \%$ bean hay (BH) $(v / v), 80 \%$ SGFW $+20 \%$ chicken manure (including wheat hay) (CMH) ( $v / v)$ and $100 \%$ SGFW. Results showed that $100 \%$ SGFW compost had a suitable pH and EC with 7.82 and $1.68 \mathrm{dSm}^{-1}$, respectively. Also, 80\% SGFW + 20\% BH compost was very rich in organic matter similar to coco peat, but $80 \% \mathrm{SGFW}+20 \% \mathrm{CMH}$ compost had the lowest $\mathrm{C} / \mathrm{N}$ ratio (5.2). The N, $P$ and $K$ concentrations in SGFW composts were higher than the coco peat or vermiculite. The soluble cations $\left(\mathrm{Ca}^{2+}, \mathrm{Mg}^{2+}, \mathrm{K}^{+}\right)$and anions $\left(\mathrm{CO}_{3}^{2-}, \mathrm{HCO}_{3}^{-}\right)$in $60 \% \mathrm{SGFW}+40 \% \mathrm{CMS}$ compost were the highest among substrates. The concentrations of trace elements and heavy metals in SGFW composts were far lower than the range of phytotoxicity. On the other hand, total phenols in SGFW composts were higher than coco peat.

\section{Keywords}

Grape Waste, Compost, Coco Peat, Macro-Element, Anions

\section{Introduction}

Growing media are various materials, other than soils in situ, in which plants are grown [1]. For the grower, it is

"Corresponding author.

How to cite this paper: El-Mahrouk, M.E. and Dewir, Y.H. (2016) Physico-Chemical Properties of Compost Based WasteRecycling of Grape Fruit as Nursery Growing Medium. American Journal of Plant Sciences, 7, 48-54. 
essential that the growing medium is suitable and stable under his growing conditions. Substrate cost is important in decision grower to purchase those materials. Wastes are major environmental issues worldwide. Wastes products had toxic effects on plants, animals and several useful organisms due to phenol and none digested organic matter contents. Accordingly, grape pruning and manufacture wastes are rich in phenolic compounds [2]. Grape waste manufactories in the world have shown increasing interest in producing compost from grape wastes to reduce environment pollution. Also, this compost resulted from grape wastes can be applied to poor soils as a nutrient rich soil conditioner or used as alternative media in nurseries. There are many reports to use grape waste compost from fruits and pruning as a growing media of seedling production [3] on tomato and Cockscomb, or use for amending the soil properties and improving the plant growth [4] on cucumber, [5] on tomato and cucumber. The previous studies determined the quality of compost based grape wastes as growing media depend on the physico-chemical properties of these composts [3] [6].

Composts can be defined as any kind of treated (composted) biodegradable waste such as garden, kitchen, food, paper, card, human, manure and sewage waste. These may be sub-grouped according to their raw materials [7]. There are many uses of composts in agriculture, (1) matured composts can be alternative to peat moss in growth substrate; (2) waste recycling for compost is one method of reducing waste disposal [8]; (3) addition of compost to substrate can increase nutrients in substrate; (4) nutrient balance in plant tissues for their vigour growth [9]-[11]; (5) compost generated from different raw materials can be used as a peat substitute to control root pathogens [12]-[14].

The objective of this study was to evaluate the physico-chemical properties of different mixtures of squeezed grape fruits waste (SGFW), chicken manure (including sawdust or wheat hay) (CMS or CMH) and beans hay $(\mathrm{BH})$ as growing media in nurseries.

\section{Materials and Methods}

The study was conducted in one year (2014) in the nursery of El-Kenana Company located in Tanta governorate, Egypt for composting different mixtures of squeezed grape fruits waste (SGFW), chicken manure (including sawdust or wheat hay) (CMS or CMH) and beans hay (BH).

\subsection{Composting Process}

Squeezed grape fruit waste (SGFW) of Roomy Red cultivar was purchased from Alahruam Drinks manufacture, Elbhera, Egypt in September 2012 and divided into four groups. Each group was mixed with other materials to improve and accelerate the composting. The following materials were composted: A) $60 \%$ SGFW $+40 \%$ chicken manure (including sawdust) (CMS) $(v / v)$, B) $80 \%$ SGFW + 20\% beans hay (BH) $(v / v)$, C) $80 \%$ SGFW + $20 \%$ chicken manure (including wheat hay) $(\mathrm{CMH})(v / v)$ and D) 100\% SGFW. All waste materials were composted as previously described of grape waste by [3]. The wastes were arranged in heaps at $2 \mathrm{~m}$ wide $\times 1.5 \mathrm{~m}$ tall $\times 20 \mathrm{~m}$ long, which were regularly turned and crushed using compost machine, and watered for three months to ensure appropriate composting conditions. Heaps were watered with sprinkler system when needed (at field capacity point) and turned weekly to ensure adequate aeration and high decomposition. Maturity of composts considered complete when the temperature inside the heap decreased to the surrounding temperature. After composting the $\mathrm{C} / \mathrm{N}$ ratio was lower than for compost compare with raw materials before composting.

\subsection{Chemical Analysis}

Different composts (3 months after the start of the composting process) and both Coco peat and vermiculite as a control were chemically analyzed (using Sigma chemical company with $97 \%$ purity) by the accredited central laboratory of Kafrelsheikh University, Egypt according to ISO 17025. Chemical analyses were carried out as follows: $\mathrm{pH}$ and $\mathrm{EC}$ were determined in aqueous compost extracts which were prepared by shaking the compost in distilled water at a ratio of $1: 10(w / v)$ for $2 \mathrm{~h}$ at room temperature. The suspension was centrifuged and the supernatant was filtered through filter paper. $\mathrm{pH}$ and EC were determined in compost extract according to [15]. Organic matter content was determined using Loos-on ignition is a modification of a method described by [16]. Soluble cations, $\mathrm{Na}^{+}, \mathrm{K}^{+}, \mathrm{Ca}^{2+}$ and $\mathrm{Mg}^{2+}$ were estimated using atomic absorption spectrometry method according to [17]. $\mathrm{N}$ content was measured on dry matter using the Kieldahl method [18]. Soluble anions, $\mathrm{CO}_{3}^{2-}$ and $\mathrm{HCO}_{3}^{-}$were determined volumetrically [19], $\mathrm{Cl}^{-}$was determined following Mohr's method and $\mathrm{SO}_{4}^{2-}$ was 
computed from the difference between sum of the cations and the anions according to [17]. Total heavy metals were estimated in one gram of each sample and digested by using dry aching method in a muffle at $450^{\circ} \mathrm{C}$ for five hours and the ash was extracted using $20 \%$ hydrochloric acid [20]. All tested heavy metals were estimated using atomic absorption spectrometry. Total phenol was extracted from $1 \mathrm{~g}$ dried powder of each compost sample by methanol (95\%) for $1 \mathrm{~h}$ at $40^{\circ} \mathrm{C}$ with stirring. After cooling at room temperature, the extracts were filtered and dried at $40^{\circ} \mathrm{C}$ to obtain methanol crude extract. All extracts were separately dissolved in methanol to prepare stock solution. After that, total phenol was determined according to the Folin-Ciocalteu procedure [21]. Briefly, $1.0 \mathrm{ml}$ Folin-Ciocalteu's reagent (50\%) and $0.8 \mathrm{ml} \mathrm{7.5 \%} \mathrm{(w/v)} \mathrm{Na}_{2} \mathrm{CO}_{3}$ were added to $0.2 \mathrm{ml}$ of methanolic solution of the sample. After shaking, the mixture was incubated at room temperature for $30 \mathrm{~min}$. Absorption was measured at $765 \mathrm{~nm}$ using Abbota SM 1200 UV-VIS spectrometer, New Jersey (USA). Total phenolic content was expressed as gallic acid equivalents (GAE) in $\mathrm{mg} / \mathrm{kg}$ DW.

\subsection{Statistical Analysis}

Experiments were set up in a completely randomized design in three replicates. The mean and one-way ANOVA were calculated using SPSS (version 20) software. The mean separations were carried out using Duncan's multiple range tests [22] and significance was determined at $p \leq 0.05$.

\section{Results and Discussion}

\subsection{Physico-Chemical Properties, C/N Ratio, Organic Matter (OM), Organic Carbon (OC) and Macronutrient Contents of Substrates}

Physico-chemical properties, $\mathrm{C} / \mathrm{N}$ ratio, organic matter (OM), organic carbon (OC) and macronutrient contents of substrates are presented in Table 1. Composts and vermiculite had the highest $\mathrm{pH}$ values ranged from 7.82 to 8.98 (but these values are in suitable range of growth medium) when compared with coco peat $\mathrm{pH}(5.31)$. The compost $\mathrm{pH}$ value ranging from 5.5 to 8.5 is considered acceptable [23]. While, the lowest EC value was observed in vermiculite $\left(0.18 \mathrm{dSm}^{-1}\right)$. Also, $80 \%$ SGFW $+20 \% \mathrm{CMH}$ and $100 \%$ SGFW substrates had acceptable limits for EC 1.36 and $1.68 \mathrm{ds} / \mathrm{m}$, respectively. On the other hand, coco peat and other composts media had the highest EC values. These values are in the limit of recommended values $0.75-1.99 \mathrm{dSm}^{-1}$ [24]. Many studies showed that $\mathrm{pH}$ and EC are considered important compost parameters because they can affect the quality and suitability of the final product for plant growth [24] [25]. These results are in agreed with [3] [8] [26] they found that compost $\mathrm{pH}$ and EC values were in all cases higher than peat. The highest organic matter (50\%) and carbon percentage (35\%) were observed on $80 \%$ SGFW $+20 \%$ BH and coco peat substrates. The other media contained over $22 \%$ and $15 \%$ of OM and OC, respectively. Vermiculite does not contain OM and OC. It is known that the $\mathrm{OM}$ content should be decreased during composting process. The loss of OM content during composting was due to its conversion into $\mathrm{CO}_{2}, \mathrm{H}_{2} \mathrm{O}$ and energy in one part while the remaining part is converted into stable organic compounds [25] [27]. There were significant differences among substrates on macronutrient contents

Table 1. Physicochemical properties, $\mathrm{C} / \mathrm{N}$ ratio, organic matter (O.M), organic carbon (O.C) and macronutrient contents of composts, coco peat and vermiculite.

\begin{tabular}{|c|c|c|c|c|c|c|c|c|c|}
\hline Composts & $\mathrm{pH}$ & $\mathrm{EC}\left(\mathrm{dSm}^{-1}\right)$ & O.M \% & O.C \% & $\mathrm{Mg} \mathrm{mg} / \mathrm{kg}$ & $\mathrm{N} \mathrm{mg} / \mathrm{kg}$ & $\mathrm{P} \mathrm{mg} / \mathrm{kg}$ & $\mathrm{K} \mathrm{mg} / \mathrm{kg}$ & $\mathrm{C} / \mathrm{N}$ \\
\hline $60 \%$ SGFW $+40 \%$ CMS & $8.98 a^{z}$ & $2.34 \mathrm{a}$ & $32.3 \mathrm{~b}$ & $22.61 \mathrm{~b}$ & 2825 c & $21420 \mathrm{~b}$ & 4633 a & 14660 c & $10.56 \mathrm{c}$ \\
\hline $80 \%$ SGFW $+20 \% \mathrm{BH}$ & $8.51 \mathrm{ab}$ & $2.29 \mathrm{~b}$ & $50.1 \mathrm{a}$ & 35.07 a & $1200 \mathrm{~d}$ & $22960 \mathrm{~b}$ & $3340 \mathrm{~b}$ & $12565 \mathrm{~d}$ & $15.27 \mathrm{~b}$ \\
\hline $80 \%$ SGFW + $20 \% \mathrm{CMH}$ & $8.12 \mathrm{~b}$ & $1.36 \mathrm{~d}$ & $22.3 \mathrm{c}$ & $15.61 \mathrm{c}$ & $1200 \mathrm{~d}$ & 30800 a & $3316 b$ & $16755 b$ & $5.2 \mathrm{~d}$ \\
\hline $100 \%$ SGFW & $7.82 \mathrm{c}$ & $1.68 \mathrm{c}$ & $32.2 \mathrm{~b}$ & $22.54 \mathrm{~b}$ & $1250 \mathrm{~d}$ & $21140 \mathrm{~b}$ & $3292 b$ & 18845 a & $10.73 \mathrm{c}$ \\
\hline Coco peat & $5.31 \mathrm{~d}$ & $2.49 \mathrm{a}$ & $50.8 \mathrm{a}$ & 35.56 a & $4025 \mathrm{~b}$ & $6500 \mathrm{c}$ & 395 c & 14660 c & $54.7 \mathrm{a}$ \\
\hline Vermiculite & $8.62 \mathrm{ab}$ & 0.18 e & $0.0 \mathrm{~d}$ & $0.0 \mathrm{~d}$ & 26525 a & $250 \mathrm{~d}$ & $155.5 \mathrm{~d}$ & 2596 e & $0.0 \mathrm{e}$ \\
\hline Significance & $* *$ & ** & $* *$ & $* *$ & $* *$ & $* *$ & $* *$ & $* *$ & $* *$ \\
\hline
\end{tabular}

\footnotetext{
${ }^{\mathrm{z}}$ Values followed by the same letter in the same column are not significantly at the 95\% level according to Duncan's test, $\mathrm{n}=3$.
} 
depending on the nutrient element. Chemical analysis showed that vermiculite was rich in magnesium (Mg) content, while $80 \%$ SGFW $+20 \%$ CMH compost was rich in nitrogen $(\mathrm{N})$ content. Also, the highest contents of phosphorus (P) and potassium (K) were observed on $60 \%$ SGFW $+40 \%$ CMS and $100 \%$ SGFW composts, respectively. It is obvious that composts had nutrient elements similar to that of coco peat. Therefore, SGFW composts can be considered an alternative to the standard medium used in the nurseries. These results are in accordance with [28] that compost and substrate-based compost is very rich in macronutrients (N, P, K) as compared with peat. The $\mathrm{C} / \mathrm{N}$ ratio is important indicator for maturity, quality and stability of final compost product because of its effect on immobilization and release of nitrogen and other important nutrients in the soil [26]. Zero value of $\mathrm{C} / \mathrm{N}$ ratio was observed on vermiculite substrate because it does not contain organic matter. Therefore, $80 \%$ SGFW $+20 \%$ CMH compost had the lowest value of $\mathrm{C} / \mathrm{N}$ ratio (5.2) when compared with other composts and coco peat. Also, all composts had C/N ratio values (5.2 to 15.27) lower than coco peat (54.7). The $\mathrm{C} / \mathrm{N}$ ratio which is less than 20 is indicative of an acceptable maturity and ideal for nursery plant production [29], a ratio of 15 or even less being most preferable [30], but the Ratio above 30 may be toxic, causing plant death [31]. The C/N ratio values of SGFW composts are acceptable to use in the nurseries as compared with coco peat alone without fertilization. Similar finding has been reported by [32]. They found that an increased proportion of compost in crop substrates prompted a decline in the $C / N$ ratio compared to peats.

\subsection{Soluble Cations and Anions of Substrates}

Chemical analysis of soluble cations and anions are displayed in Table 2. All substrates had significant differences on soluble cations and anions. From that, $60 \%$ SGFW + 40\% CMS medium had a significant increase in $\mathrm{Ca}^{2+}, \mathrm{Mg}^{2+}, \mathrm{K}^{+}, \mathrm{CO}_{3}^{2-}$ and $\mathrm{HCO}_{3}^{-}$at 320, 96, 4953, 120 and $5124 \mathrm{mg} / \mathrm{kg}$, respectively. Also, 80\% SGFW+ $20 \% \mathrm{BH}$ was rich in $\mathrm{Mg}^{2+}$, $\mathrm{K}^{+}$and $\mathrm{SO}_{4}^{2-}$ with 96,4953 and $5232 \mathrm{mg} / \mathrm{kg}$, respectively. The wastes of CMS and $\mathrm{BH}$ added to SGFW substrate during the composting process improved the compost quality and soluble cations and anions as compared with pure SGFW. On the other hand, coco peat had a significant increase of $\mathrm{Na}^{+}$and $\mathrm{Cl}^{-}$with 2438 and $7242 \mathrm{mg} / \mathrm{kg}$, respectively. Also, vermiculite was rich in $\mathrm{Ca}^{2+}$ and $\mathrm{Mg}^{2+}$ with 320 and 96 $\mathrm{mg} / \mathrm{kg}$. [33] [34] observed that total salts were higher in mixed waste composts, predominantly due to high concentrations of $\mathrm{K}^{+}, \mathrm{Ca}^{2+}, \mathrm{SO}_{4}^{2-}$, and $\mathrm{Na}^{+}$. On contrast, several studies showed that leaching of compost decreased the soluble mineral elements, mainly $\mathrm{SO}_{4}^{2-}, \mathrm{K}^{+}, \mathrm{Cl}^{-}, \mathrm{Mg}^{2+}, \mathrm{Ca}^{2+}$ and $\mathrm{Na}^{+}$, to acceptable levels [35].

\subsection{Trace Elements, Heavy Metals and Total Phenol Contents of Substrates}

Trace elements, heavy metals and total phenols contents are showed in Table 3. Vermiculite was rich in micronutrients such as Mn and Fe with 7800 and $14975 \mathrm{mg} / \mathrm{kg}$, respectively as compared with other substrates. Also, all composts showed increase in micronutrients than coco peat. The highest content of $\mathrm{Zn}$ (73 mg/kg) was observed in $60 \%$ SGFW $+40 \%$ CMS medium. In addition, all substrates were free from $\mathrm{Pb}$ and $\mathrm{Cd}$ except vermiculite contained 15 and $1.2 \mathrm{mg} / \mathrm{kg}$, respectively. Although, all substrates contained $\mathrm{Zn}$ and $\mathrm{Cu}$ but their contents were

Table 2. Soluble cations and anions of composts, coco peat and vermiculite.

\begin{tabular}{|c|c|c|c|c|c|c|c|c|}
\hline \multirow{2}{*}{ Composts } & \multicolumn{4}{|c|}{ Soluble cations (mg/kg) } & \multicolumn{4}{|c|}{ Soluble anions (mg/kg) } \\
\hline & $\mathrm{Ca}^{2+}$ & $\mathrm{Mg}^{2+}$ & $\mathrm{Na}^{+}$ & $\mathrm{K}^{+}$ & $\mathrm{Cl}^{-}$ & $\mathrm{CO}_{3}^{2-}$ & $\mathrm{HCO}_{3}^{-}$ & $\mathrm{SO}_{4}^{2-}$ \\
\hline $60 \%$ SGFW + $40 \%$ CMS & $320 a^{z}$ & 96 a & $1909 \mathrm{~b}$ & 4953 a & $3408 \mathrm{~b}$ & $120 \mathrm{a}$ & $5124 \mathrm{a}$ & $3840 \mathrm{~b}$ \\
\hline $80 \%$ SGFW + 20\% BH & $160 \mathrm{c}$ & 96 a & $1828.5 \mathrm{~b}$ & 4953 a & 3124 c & $0.0 \mathrm{~b}$ & $4392 \mathrm{~b}$ & 5232 a \\
\hline $80 \%$ SGFW + $20 \% \mathrm{CMH}$ & $80 \mathrm{~d}$ & $48 \mathrm{~b}$ & $713 \mathrm{c}$ & $3549 \mathrm{~d}$ & $1562 \mathrm{~d}$ & $0.0 \mathrm{~b}$ & 3660 c & 2112 c \\
\hline $100 \%$ SGFW & $80 \mathrm{~d}$ & $48 \mathrm{~b}$ & $874 \mathrm{c}$ & 4223.7 c & $1562 \mathrm{~d}$ & $0.0 \mathrm{~b}$ & $4392 \mathrm{~b}$ & $3292.8 \mathrm{~b}$ \\
\hline Coco peat & $240 \mathrm{~b}$ & $48 \mathrm{~b}$ & $2438 \mathrm{a}$ & $4563 \mathrm{~b}$ & $7242 \mathrm{a}$ & $0.0 \mathrm{~b}$ & $488 \mathrm{~d}$ & $1824 \mathrm{~d}$ \\
\hline Vermiculite & $320 \mathrm{a}$ & 96 a & $556.6 \mathrm{~d}$ & 50.7 e & 213 e & $0.0 \mathrm{~b}$ & $488 \mathrm{~d}$ & 2256 c \\
\hline Significance & ** & * & $* *$ & $* *$ & ** & ** & ** & ** \\
\hline
\end{tabular}

${ }^{\mathrm{z}}$ Values followed by the same letter in the same column are not significantly at the 95\% level according to Duncan’s test, $\mathrm{n}=3$. 
Table 3. Trace element, heavy metals and total phenol contents of composts, coco peat and vermiculite.

\begin{tabular}{|c|c|c|c|c|c|c|c|}
\hline Composts & $\mathrm{Mn} \mathrm{mg} / \mathrm{kg}$ & Fe mg/kg & $\mathrm{Zn} \mathrm{mg/kg}$ & $\mathrm{Cu} \mathrm{mg} / \mathrm{kg}$ & $\mathrm{Pb} \mathrm{mg} / \mathrm{kg}$ & $\mathrm{Cd} \mathrm{mg/kg}$ & Total phenol mg/kg \\
\hline $60 \%$ SGFW + $40 \%$ CMS & $106.5 b^{\mathrm{z}}$ & $1350 \mathrm{~b}$ & $73 \mathrm{a}$ & $24.5 \mathrm{a}$ & $0.0 \mathrm{~b}$ & $0.0 \mathrm{~b}$ & 1569 e \\
\hline $80 \%$ SGFW $+20 \%$ BH & $72.5 \mathrm{c}$ & 1150 c & $41.5 \mathrm{~b}$ & $21.5 \mathrm{a}$ & $0.0 \mathrm{~b}$ & $0.0 \mathrm{~b}$ & 4410 c \\
\hline $80 \%$ SGFW + $20 \% \mathrm{CMH}$ & $38.5 \mathrm{~d}$ & $750 \mathrm{~d}$ & $21 \mathrm{c}$ & $20.5 \mathrm{ab}$ & $0.0 \mathrm{~b}$ & $0.0 \mathrm{~b}$ & $5625 \mathrm{~b}$ \\
\hline $100 \%$ SGFW & $35.5 \mathrm{~d}$ & $750 \mathrm{~d}$ & $20 \mathrm{c}$ & $17.5 \mathrm{~b}$ & $0.0 \mathrm{~b}$ & $0.0 \mathrm{~b}$ & 7343 a \\
\hline Coco peat & $21.5 \mathrm{e}$ & 298.5 e & $12 \mathrm{~d}$ & $3.5 \mathrm{c}$ & $0.0 \mathrm{~b}$ & $0.0 \mathrm{~b}$ & 2591d \\
\hline Vermiculite & 7800 a & 14975 a & $23 \mathrm{c}$ & $22 \mathrm{a}$ & $15 \mathrm{a}$ & $1.2 \mathrm{a}$ & $0.0 \mathrm{f}$ \\
\hline Limit values $^{\mathrm{Y}}$ & - & - & 1500 & 500 & 1000 & 5 & - \\
\hline Limit values ${ }^{\mathrm{x}}$ & - & - & 300 & 75 & 140 & 1.5 & - \\
\hline Significance & ** & ** & $* *$ & ** & $* *$ & $* *$ & ** \\
\hline
\end{tabular}

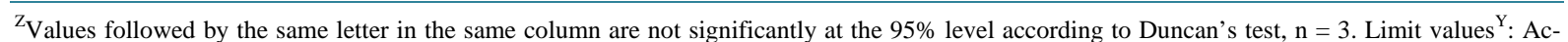
cording to Abad et al. (1993). Limit values ${ }^{\mathrm{X}}$ : European Commission (2001/688/EC). Establishing ecological criteria for the award of the Community eco-label to soil improvers and growing media (noti Wed under document number C (2001) 2597).

still below standard limits according to [24] [36]. It has been noticed that 100\% SGFW medium had the highest value of total phenolic compounds $(7343 \mathrm{mg} / \mathrm{kg}$ ) followed by $80 \%$ SGFW $+20 \%$ CMH medium which contained $5625 \mathrm{mg} / \mathrm{kg}$. On the other hand, zero value of total phenolic compounds was observed in vermiculite substrate. The results of our study confirm that grape wastes are rich in phenolic compounds [2] [37].

\section{Conclusion}

The substrates $80 \%$ SGFW $+20 \%$ CMH and 100\% SGFW had acceptable limits for EC. The highest organic matter and carbon percentage were observed on $80 \%$ SGFW $+20 \%$ BH and coco peat substrates. $80 \%$ SGFW + $20 \%$ CMH compost was rich in nitrogen $(\mathrm{N})$ content while, $60 \%$ SGFW + 40\% CMS compost had the highest contents of phosphorus (P) and potassium (K). In addition, 60\% SGFW + 40\% CMS medium had a significant increase in $\mathrm{Ca}^{2+}, \mathrm{Mg}^{2+}, \mathrm{K}^{+}, \mathrm{CO}_{3}^{2-}$ and $\mathrm{HCO}_{3}^{-}$. All substrates were free from $\mathrm{Pb}$ and $\mathrm{Cd}$ except vermiculite. Pure SGFW composts are not recommended due to its high pH, EC and phytotoxic compounds.

\section{Acknowledgements}

The authors are grateful for great support from Elkenana Company and analysis assistance provided by Dr. Abd Elnaser Elzaawely, Tanta University.

\section{References}

[1] CEN (1999) CR 13456:1999-Soil Improvers and Growing Media—Labelling, Specifications and Product Schedules. European Committee for Standardisation, Brussels, $50 \mathrm{p}$.

[2] Diaz, M.J., Madejon, E., Cabreera, F., Jimenez, L. and De Bertoldi, M. (2004) Using a Second-Order Polynomial Model to Determine the Optimum Vinasse/Grape More Ratio for in Vessel Compositing. Compost Science \& Utilization, 12, 273-279. http://dx.doi.org/10.1080/1065657X.2004.10702192

[3] Bayoumi, Y.A., El-Mahrouk, M.E., El-Aidy, F. and Pap, Z. (2008) Using Compost of Grape Manufacture and Farm Wastes as Growing Media in Vegetable and Ornamental Nurseries. International Journal of Horticulture Science, 14, 45-50.

[4] Kostov, O., Tzvetkov, Y., Kaloianova, N. and Van Cleemput, O. (1995) Cucumber Cultivation on Some Wastes during Their Aerobic Composting. Bioresource Technology, 53, 237-242. http://dx.doi.org/10.1016/0960-8524(95)00076-Q

[5] Jahromi, M.G., Aboutalebi, A. and Farahi, M.H. (2012) Influence of Different Levels of Garden Compost (Garden Wastes and Cow Manure) on Growth and Stand Establishment of Tomato and Cucumber in Greenhouse Condition. African Journal of Biotechnology, 11, 9036-9039.

[6] Zmora-Nahum, S., Hadar, Y. and Chen, Y. (2007) Physico-Chemical Properties of Commercial Composts Varying in Their Source Materials and Country of Origin. Soil Biology \& Biochemistry, 39, 1263-1276. 
http://dx.doi.org/10.1016/j.soilbio.2006.12.017

[7] Schmilewski, G. (2008) The Role of Peat in Assuring the Quality of Growing Media. Mires and Peat, 3, 1-8.

[8] Ostos, J.C., López-Garrido, R., Murillo, J.M. and López, R. (2008) Substitution of Peat for Municipal Solid Waste- and Sewage Sludge-Based Composts in Nursery Growing Media: Effects on Growth and Nutrition of the Native Shrub Pistacia lentiscus L. Bioresource Technology, 99, 793-800. http://dx.doi.org/10.1016/j.biortech.2007.03.033

[9] Linhart, Y.B., Mooney, K.A., Snyder, M.A. and Swoboda-Colberg, N. (2001) Phloem Chemistry: Effect of Genotype and Environment Implications for Nutritional Ecology. International Journal of Plant Sciences, 162, $433-447$. http://dx.doi.org/10.1086/321925

[10] Alonso, C. and Herrera, C.M. (2003) Developmental and Spatial Covariation of Nutrients in Growing Leaves of Daphne laureola and Their Relationship with Herbivory. New Phytologist, 159, 645-656. http://dx.doi.org/10.1046/j.1469-8137.2003.00831.x

[11] Grigatti, M., Giorgioni, M.E. and Ciavatta, C. (2007) Compost-Based Growing Media: Influence on Growth and Nutrient Use of Bedding Plants. Bioresource Technology, 98, 3526-3534. http://dx.doi.org/10.1016/j.biortech.2006.11.016

[12] Cotxarrera, L., Trillas-Gay, M.I., Steinberg, C. and Alabouvette, C. (2002) Use of Sewage Sludge Compost and Trichoderma asperellum Isolates to Suppress Fusarium wilt of Tomato. Soil Biology and Biochemistry, 34, 467-476. http://dx.doi.org/10.1016/S0038-0717(01)00205-X

[13] Borrero, C., Trillas, M.I., Ordovás, J., Tello, J. and Avilés, M. (2004) Predictive Factors for the Suppression of Fusarium wilt of Tomato in Plant Growth Media. Phytopathology, 94, 1094-1101. http://dx.doi.org/10.1094/PHYTO.2004.94.10.1094

[14] Litterick, A.M., Harrier, L., Wallace, P., Watson, C.A. and Wood, M. (2004) The Role of Uncomposted Materials, Composts, Manures and Compost Extracts in Reducing Pest and Disease Incidence and Severity in Sustainable Temperate Agricultural and Horticultural Crop Production-A Review. Critical Reviews in Plant Sciences, 23, 453-479. http://dx.doi.org/10.1080/07352680490886815

[15] Page, A.L., Miller, R.H. and Keeney, P.R. (1982) Methods of Soil Analysis. American Society of Agronomy Inc. Publisher, Madison.

[16] Ben-Dor, E. and Banin, A. (1989) Determination of Organic Matter Content in Arid Zone Soils Using a Simple "Loss-on-Ignition" Method. Communications in Soil Science and Plant Analysis, 20, 1675-1695. http://dx.doi.org/10.1080/00103628909368175

[17] USDA (2004) Soil Survey Laboratory Methods Manual. Soil Survey Investigation Report No. 42, Version 4.

[18] Bremnen, J.M. (1996) Nitrogen-Total. In: Sparks, D.L., Ed., Methods of Soil Analysis, SSA, Madison, 1085-1121.

[19] Black, C.A. (1965) Methods of Soil Analysis: Part I, Physical and Mineralogical Properties. American Society of Agronomy, Madison, Wisconsin.

[20] Jones, B.J., Symon, C., Tylor, P.J.L., Walsh, J. and Johnston, A.E. (1991) Evidence for a Decline in Rural Herbage Lead Levels in the UK. Atmosphere and Environment, 25, 361-369. http://dx.doi.org/10.1016/0960-1686(91)90307-S

[21] Folin, O. and Ciocalteu, V. (1927) On Tyrosine and Tryptophane Determinations in Proteins. Journal of Biological Chemistry, 73, 627-650.

[22] Duncan, D.B. (1955) Multiple Range and Multiple F Tests. Biometrics, 11, 1-42. http://dx.doi.org/10.2307/3001478

[23] Silva, M.E.F., Lemos, L.T., Bastos, M.M.S.M. and Nunes, O.C. (2013) Recovery of Humic like Substances from Low Quality Composts. Bioresource Technology, 128, 624-632. http://dx.doi.org/10.1016/j.biortech.2012.11.013

[24] Abad, M., Martınez, P.F., Martınez, M.D. and Martınez, J. (1993) Evaluacion agronomica de los sustratos de cultivo. Actas de Horticultura, 11, 141-154.

[25] Nakhshinieva, B., Biddinikaa, M.K., Gonzales, H.B., Sumidac, H. and Yoshikawaa, K. (2014) Evaluation of Hydrothermal Treatment in Enhancing Rice Straw Compost Stability and Maturity. Bioresource Technology, 151, $306-313$. http://dx.doi.org/10.1016/j.biortech.2013.10.083

[26] Herrera, F., Castillo, J.E., Chica, A.F. and Lopez Bellido, L. (2008) Use of Municipal Solid Waste Compost (MSWC) as a Growing Medium in the Nursery Production of Tomato Plants. Bioresource Technology, 99, 287-296. http://dx.doi.org/10.1016/j.biortech.2006.12.042

[27] Insam, H. and De Bertoldi, M. (2007) Microbiology of Composting Process. In: Diaz, L.F., de Bertoldi, M., Bidlingmaier, W. and Stentiford, E., Eds., Compost Science andTechnology, Waste Management Series, Elsevier Science, Amsterdam, 26.

[28] Kahn, B.A., Hyde, J.K., Cole, J.C., Stoffella, P.J. and Graetz, D.A. (2005) Replacement of a Peat-Lite Medium with Compost for Cauliflower Transplant Production. Compost Science Utilization, 13, 175-179. http://dx.doi.org/10.1080/1065657X.2005.10702238 
[29] Davidson, H., Mecklenburg, R. and Peterson, C. (1994) Nursery Management: Administration and Culture. Third Edition, Prentice Hall, Englewood Cliffs.

[30] Jimenez, E.I. and Garcia, V.P. (1989) Evaluation of City Refuse Compost Maturity: A Review. Biological Wastes, 27, 115-142. http://dx.doi.org/10.1016/0269-7483(89)90039-6

[31] Zucconi, F., Pera, A., Forte, M. and DeBertolli, M. (1981) Evaluating Toxicity of Immature Compost. Biocycle, 22, 54-57.

[32] Wilson, S.B., Stoffella, P.J. and Graetz, D.A. (2001) Evaluation of Compost as an Amendment to Commercial Mixes Used for Container-Grown Golden Shrimp Plant Production. HortTechnology, 11, 31-35.

[33] Dimanmbro, M.E., Lillywhite, R.D. and Ranh, C.R. (2007) The Physical, Chemical and Microbial Characteristics of Biodegradable Municipal Waste Derived Composts. Compost Science \& Utilization, 15, 243-252. http://dx.doi.org/10.1080/1065657X.2007.10702340

[34] Carrión, C., Abad, M., Maquieira, A., Puchades, R., Fornes, F. and Noguera, V. (2005) Leaching of Composts from Agricultural Wastes to Prepare Nursery Potting Media. Acta Horticulturae, 697, 117-124. http://dx.doi.org/10.17660/ActaHortic.2005.697.13

[35] Mazuela, P. and Urrestarazu, M. (2009) The Effect of Amendment of Vegetable Waste Compost Used as Substrate in Soilless Culture on Yield and Quality of Melon Crops. Compost Science \& Utilization, 17, 103-107. http://dx.doi.org/10.1080/1065657X.2009.10702408

[36] Ecolabel, 2001/688/CE (2001) European Commission (2001/688/EC). Establishing Ecological Criteria for the Award of the Community Eco-Label to Soil Improvers and Growing Media (Noti-Wed under Document Number C 2597).

[37] Inber, Y., Chen, Y. and Hadar, H. (1991) Carbon 13 CPMAs, NMR and FTIR. Spectroscopic Analysis of Organic Matter Transformation during Composting of Solid Wastes from Wineries. Soil Science, 152, 272-282.

http://dx.doi.org/10.1097/00010694-199110000-00005 